спостереження, оцінка, контроль за рівним економічної безпеки та розподіл обов'язків за цими діями є одним із основним завдань сучасного підприємства.

1. Вавдіюк Н.С., Герасимчук 3.В. Економічна безпека регіону діагностика та механізм забезпечення: монографія Луцьк 2006. 243 с.

2. Васильців Т. Г. Економічна безпека підприємництва України: стратегія та механізми зміцнення: монографія Львів: Арал, 2008. 384 с.

3. Дацків Р. М. Економічна безпека у глобальному вимірі. Актуальні проблеми економіки. 2014. № 7 (37). С. 143-153.

4. Картузов С. П. Вплив ризиків і загроз на стан фінансової безпеки підприємств. Економіка та управління підприємствами. 2012. № 9 (135). С. 115-124

5. Коваленко О.В., Лисенко Л.В. Підходи до визначення поняття економічної безпеки підприємства. Глобальні та національні проблеми економіки, 2014. № 6. С. 48-57.

6. Меліхова Т. О. Механізм управління економічною безпекою підприємства: підходи до визначення. Агросвіт № 3,2018

7. Отенко І. П., Іващенко Г. А., Воронков Д. К. Економічна безпека підприємства: навч. посіб. Харків. Вид. ХНЕУ, 2012. 313 с.

8. Хоменко О.А Аналіз ідентифікації ознак механізму управління фінансовою безпекою молокопереробних підприємств Економічний дискурс Міжнародний науковий журнал Випуск 1. 2019

9. Худолій Л. М. складові економічної безпеки суб'єктів господарської діяльності. Ефективна економіка. 2017. № 1. С. 36 - 45.

*УДК 657.37:330

Шевчук К.В., к.е.н., доцент

Бондар B.I.

Національний університет біоресурсів і природокористування України

\title{
ФІНАНСОВІ РЕЗУЛЬТАТИ ЯК ЕКОНОМІЧНА КАТЕГОРІЯ ТА ОСОБЛИВОСТІ ВІДОБРАЖЕННЯ ЇХ В ОБЛІКУ ТА ЗВІТНОСТІ ПІДПРИЕМСТВА
}

У статті розглянуто сутність фінансових результатів діяльності підприємства, визначено їх місце у системі бухгалтерського обліку та звітності суб'єктів господарювання. Виділено та узагальнено проблеми інформаційного забезпечення процесу управління фінансовими результатами.

* Шевчук К.В., Бондар В.I. 
Досліджено проблемні аспекти формування внутрішньої звітності в сучасних умовах господарювання, визначено інформаційні вимоги користувачів до внутрішньої звітності, запропоновано підхід до їі формування.

Ключові слова: фінансові результати підприємства, прибуток, збиток, внутрішня звітність, управлінський персонал.

\section{Shevchuk K., Bondar V. FINANCIAL RESULTS AS THE ECONOMIC CATEGORY AND
THE FEATURES OF DISPLAYING THEIR IN THE
ACCOUNTING AND REPORTING OF THE ENTERPRISE}

The article deals with the essence of financial results of the enterprise activity, defines their place in the accounting and reporting of economic entities. The problems of information support of the process of financial results management are highlighted and generalized. The problems of internal reporting formation in modern business conditions are considered, the information requirements of users to internal reporting are defined, the approach to its formation is proposed.

Understanding the essence of the category «financial result» - one of the main prerequisites for the formation of appropriate areas of its accounting, analysis and control, as well as the ability to exercise managerial influence on its individual components in order to improve the efficiency of the enterprise. The assessment of the legal and regulatory support indicates that the term «financial results» is not defined in detail in the legislation of Ukraine.

Thus, national $\mathrm{R}(\mathrm{S})$ of Accounting 1 «General Financial Reporting Requirements» defines the economic content of the categories «profit» and «loss». The concepts of «financial result» and «profit» are not identical, since the category «financial result» is broader in its meaning. The financial results reflect the entire economic activity of the enterprise, characterize the quantitative and qualitative indicators of the performance of the enterprise. Profit or loss is the result of this activity. The positive value of the financial result (profit) is an important indicator of growth of equity capital, which ensures solvency, financial independence, business reputation and growth of the enterprise value in the market.

The following definition of this economic category is appropriate: financial results is a monetary indicator of the performance of an entity's economic activity, which is determined by comparing the income received and expenses incurred. Performance indicators can be expressed in the form of profit or loss.

According to the current regulatory documents, information about financial results is disclosed in almost all forms of financial statements of domestic enterprises, but in different interpretations. It is important to report on information sufficient for strategic profit management. For its formation it is necessary to take into account the factors that determine the value of the financial result of each particular enterprise.

Modern trends in the financial statements reinforce attention to the notes to the financial statements, which revealed, refined and supplemented by information provided in the basic reporting forms. An important direction of increasing the level of financial reporting analytics should be the proper construction of its form. 
In developing forms of internal (management) reporting, the existing reporting requirements (defined at the legislative level), in practice, act as a limiting factor, since they often do not take into account the features of the enterprise management system and activity strategy. Therefore, it is important to generate sufficient information in the accounts to support strategic revenue management.

Key words: financial results, profit, loss, internal reporting, management.

Шевчук Е.В., Бондарь В.И.

\section{ФИНАНСОВЫЕ РЕЗУЛЬТАТЫ КАК ЭКОНОМИЧЕСКАЯ КАТЕГОРИЯ И ОСОБЕННОСТИ ОТОБРАЖЕНИЯ ИХ В УЧЕТЕ И ОТЧЕТНОСТИ ПРЕДПРИЯТИЯ}

В статье рассмотрена сущность финансовых результатов деятельности предприятия, определено их место в системе бухгалтерского учета и отчетности хозяйствующих субъектов. Выделены и обобщены проблемы информационного обеспечения процесса управления финансовыми результатами. Исследованы проблемные аспекты формирования внутренней отчетности в современных условиях хозяйствования, определены информационные требования пользователей к внутренней отчетности, предложен подход к ее формированию.

Ключевые слова: финансовые результаты предприятия, прибыль, убыток, внутренняя отчетность, управленческий персонал.

Постановка проблеми у загальному вигляді та її зв'язок $з$ важливими науковими та практичними завданнями. В ринкових умовах господарювання діяльність кожного суб'єкта господарювання спрямована на отримання економічної вигоди, що знаходить відображення у фінансових результатах. В системі управління підприємством фінансові результати діяльності підприємства займають одне з головних місць. Складність в управлінні фінансовими результатами пов'язана 3 їх трактуванням та економічним змістом, оскільки поняття «фінансовий результат» відображаэться в узагальнених категоріях «прибуток» і «збиток», які хоч і $є$ протилежними за змістом, але мають єдиний порядок свого формування.

Система бухгалтерського обліку в Україні фактично не містить алгоритмів щодо узгодженості формування фінансових результатів у відповідності до видів діяльності. Тому, особливої актуальності набуває питання формування фінансових результатів суб'єктів господарювання та їх відображення в обліку та звітності.

Аналіз останніх досліджень, у яких започатковано вирішення проблеми. Вагомий внесок у розробку теоретикометодичних засад оцінки та формування фінансових результатів 
здійснили вчені-економісти Б.С. Грабовецький, Г.О. Крамаренко, Є.В. Мних, П.Я. Попович, І.Ф. Прокопенко, Г.Г. Кірейцев, Л.А. Лахтіонова, М.Г. Чумаченко, М.Д. Білик, Ю.С. Цал-Цалко, I.О. Бланк й ін. Питання, пов'язані з фінансовими результатами як економічною категорією, піднімалися в дисертаційних дослідженнях українських науковців І.В. Головко, М.І. Гордієнко, Я.В. Лебедзевич, С.О. Кучеркова, I.I. Мельничук, М.С. Скрипник, І.М. Динько, Т.Р. Фецович та ін. Формування показників звітності знайшли висвітлення в дослідженнях Л.М. Білої, О.М. Ганяйло, Т.С. Кучеренко, Н.В. Семенишиної, М.Р. Лучка, І.В. Семчук, Я.В. Шевері.

Цілі статті. Метою написання статті є розкриття та оцінка наукових підходів щодо економічної категорії «фінансові результати» та визначення особливостей їх відображення в бухгалтерському обліку та звітності.

Виклад основного матеріалу дослідження з повним обгрунтуванням отриманих наукових результатів. Достовірність сформованих фінансових результатів є основою принципів і правил бухгалтерського обліку, обов'язковість дотримання яких передбачено на законодавчому рівні.

Розуміння сутності категорії «фінансовий результат»- одна 3 головних передумов формування відповідних напрямків його обліку, аналізу та контролю а також можливості здійснення управлінського впливу на окремі його складові з метою підвищення ефективності діяльності підприємства.

Оцінка нормативно-правового забезпечення, свідчить про те, що в законодавстві України термін «фінансові результати» детально не визначено. В таких нормативних документах щодо організації та ведення бухгалтерського обліку як Закон України «Про бухгалтерський облік та фінансову звітність в Україні» [8], НП(С)БО 1 «Загальні вимоги до фінансової звітності» [4], М(С)БО 18 «Дохід» [3], П(С)БО 15 «Дохід» [7] визначено сутність понять «доходи», «витрати», «прибуток», «збиток». У податковому законодавстві поняття «фінансові результати» та «прибуток» ототожнюються. Статтею 134 Податкового кодексу України передбачено, що прибуток визначають зменшенням суми доходів звітного періоду на собівартість реалізованих товарів, виконаних робіт, наданих послуг та суму інших витрат звітного податкового періоду [6]. 
Трактування поняття «фінансовий результат»є неоднозначним, в тому числі в історичному контексті. Визначення фінансового результату як підсумок діяльності господарюючого суб'єкта історично привело до співіснування різних трактувань. Економічний зміст даного поняття залежить від цілей, досліджуваних у процесі господарської діяльності, від категорії користувача облікових даних, для якого проводилося виявлення фінансового результату та від набору облікових прийомів, якими володіє та чи інша облікова система [9].

Визначення економічної категорії «фінансовий результат» в економічній літературі наведено на рис. 1.

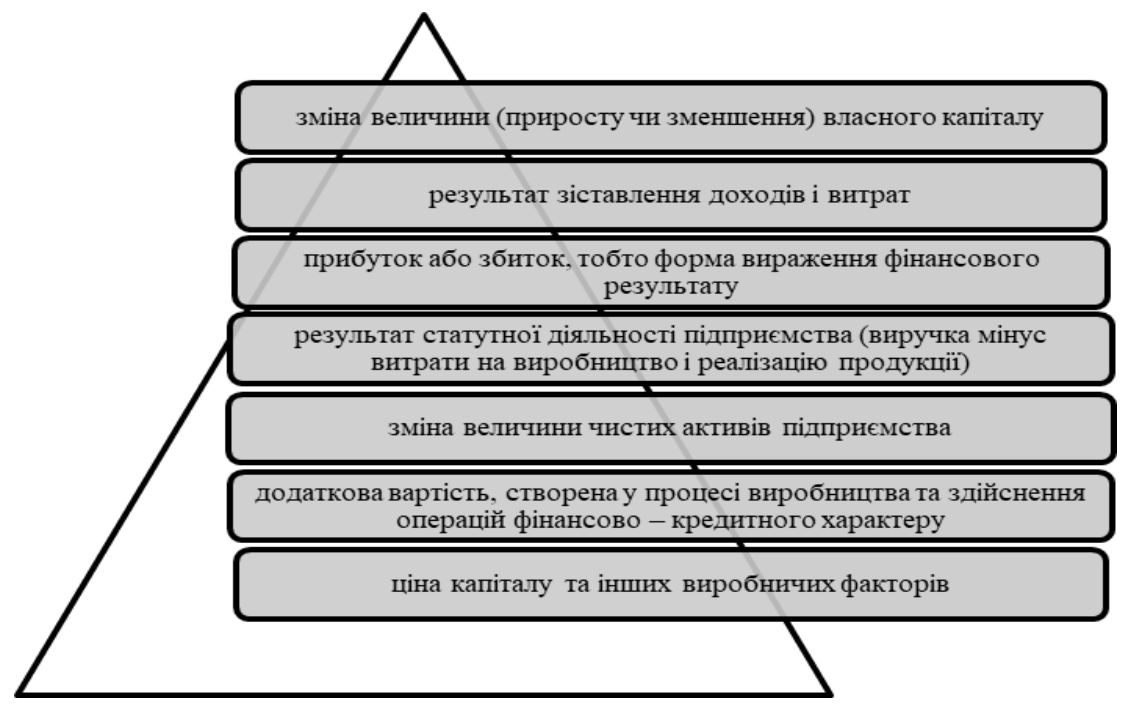

Рис. 1. Визначення економічної категорії «фінансовий результат» в економічній літературі

Вважаємо за доцільним наступне визначення даної економічної категорії: фінансові результати - це виражений в грошовій формі показник результативності господарської діяльності суб'єкта господарювання, який визначається шляхом зіставлення отриманих доходів та здійснених витрат. 
Показники результативності можуть бути виражені в формі прибутків або збитків.

Фінансові результати діяльності підприємства відображаються на рахунку 79 «Фінансові результати». Визначення фінансових результатів здійснюється через закриття субрахунків за видами діяльності (операційної, фінансових операцій та результату іншої діяльності) рахунку 79 та визначення кінцевого сальдо, яке списують на рахунок 44 «Нерозподілені прибутки (непокриті збитки)».

Синтетичний рахунок 79 «Фінансові результати» у своєму складі містить три рекомендовані субрахунки, при цьому підприємства самостійно можуть використовувати додаткові субрахунки та аналітичні рахунки, які враховують специфіку його господарської діяльності. Так деталізація субрахунку 791 «Результат операційної діяльності» за субрахунками першого, другого порядків дає можливість визначити найбільш прибуткові види продукції чи наданих послуг і вилучити з виробництва (або скоротити обсяг) малорентабельні.

Відповідно до діючих нормативних документів інформація про фінансові результати розкривається майже у всіх формах фінансової звітності вітчизняних підприємств, але у різних інтерпретаціях.

Основною складовою фінансової звітності є Баланс (Звіт про фінансовий стан) та Звіт про фінансові результати (Звіт про сукупний дохід), в яких повинні відображатися достовірні дані про фінансові результати підприємства. У Звіті про фінансові результати відображається інформація про фінансовий результат, який визначається 3 огляду на принцип нарахування та відповідності доходів і витрат.

Фінансова звітність зорієнтована на забезпечення вимог діючого законодавства в частині відображення інформації, розкриття якої є обов'язковим та на забезпечення інформаційних потреб зовнішніх користувачів. В сучасних умовах господарювання, чутливих до кризових явищ в економіці використання такої інформації обмежує їі корисність для потреб управління.

Сучасні тенденції розвитку фінансової звітності посилюють увагу на примітках до бухгалтерської фінансової звітності, в яких 
розкривається, уточнюється та доповнюється інформація, яка наведена в основних звітних формах.

Підтримуємо позицію I.А. Слободняк, О.В. Назаренко, Р.В. Лукаш, які зазначають, що з використанням єдиного формату кожної звітної форми неможливо досягти наочного представлення інформації, оскільки об'єктивно існує декілька основних напрямів економічного аналізу (горизонтальний, вертикальний, коефіцієнтний), по кожному з яких необхідно надати в розпорядження менеджера відповідну інформацію. Інформація, яка наводиться в єдиному форматі, буде або недостатньою для прийняття управлінських рішень, або, навпаки, надлишковою для конкретного рішення $[2,10]$.

Не менш важливим є формування у звітності інформації, достатньої для стратегічного управління прибутком. Для іiі формування необхідно врахувати фактори, що визначають величину фінансового результату кожного конкретного підприємства. Їх можна поділити на зовнішні (підприємство на них не впливає, але може прогнозувати їх вплив на величину фінансового результату та оцінити можливі ризики) та внутрішні (на них вплив підприємства поширюється). Саме ці внутрішні фактори потрібно враховувати максимально. Для більшої повноти охоплення варто такі фактори відображати у внутрішній звітності [1].

При розробці форм внутрішньої (управлінської) звітності існуючі вимоги до звітності (які визначені на законодавчому рівні), на практиці виступають обмежуючим фактором, оскільки досить часто не враховують особливостей сформованої на підприємстві системи управління та стратегії діяльності. Тому важливим є формування у звітності інформації, достатньої для стратегічного управління прибутком.

В ринкових умовах ефективна господарська діяльність підприємства полягає в розмежуванні облікових даних для потреб іï внутрішніх та зовнішніх користувачів. Цього можна досягти шляхом удосконалення системи аналітичного обліку.

Для задоволення інформаційних потреб користувачів інформації та забезпечення динамічності внутрішньої звітності доцільно використовувати форматний підхід до ії складання, що передбачає складання Звіту про фінансові результати з різним набором показ- 
ників, різним ступенем їх деталізації та узагальнення залежно від напрямів їх подальшого використання для потреб управління [5].

Відповідно до вимог Закону України «Про бухгалтерський облік та фінансову звітність в Україні» [8] визначено перелік підприємств, які мають складати та оприлюднювати фінансову звітність та консолідовану фінансову звітність за МСФЗ, інші українські підприємства можуть самостійно приймати рішення щодо застосування МСФЗ при складанні фінансової звітності. В Україні спостерігається позитивна динаміка до збільшення кількості підприємств, що складають фінансову звітність за МСФЗ.

Основні відмінності між національними та міжнародними стандартами щодо розкриття інформації про фінансові результати у фінансовій звітності стосуються складу фінансової звітності, концептуальних положень та принципів фінансової звітності, понять суттєвості у фінансовій звітності, звітної дати та грошового вимірника, ступеня деталізації статей, порядку відображення доходів i витрат.

Висновки. Головною метою діяльності кожного господарюючого суб'єкта є одержання та максимізація прибутку, оскільки кінцеві результати діяльності підприємства впливають не лише на його економічне становище, а й на рівень суспільного виробництва та споживання взагалі. У зв'язку з цим необхідно більш ретельно та кваліфіковано підходити до формування його складників - доходів та витрат, детально вивчаючи та аналізуючи фактори, під впливом яких формується фінансовий результат, види діяльності, досліджувати динаміку, тенденції, резерви, що впливають на ефективність діяльності підприємства.

Важливим напрямом удосконалення системи управління та системи бухгалтерського обліку є удосконалення механізму формування внутрішньої звітності про фінансові результати діяльності. Орієнтація системи бухгалтерського обліку на задоволення інформаційних запитів користувачів, передбачає необхідність впровадження форматного підходу до внутрішньої звітності. Його застосування при формуванні внутрішньої звітності про фінансові результати дозволить управлінському персоналу прослідкувати причинно-наслідкові зв'язки та тенденції, зосередити управлінський персонал на найважливіших питаннях. 
1. Гудзенко Н.М., Григораш М.В. Облік і місце фінансових результатів у звітності підприємства. Науковий вісник Херсонського державного університету. Сер.: Економічні науки. Вип. 29(2). 2018. Херсон. С. 158-160.

2. Назаренко О.В., Лукаш Р.В. Фінансові результати: сутність та особливості організації бухгалтерського обліку. Інвестиції: практика та досвід. № 22. 2018. C. 19-25.

3. М(С)БО 18 «Дохід»: Стандарт № 929_025 від 01.01.2012. URL: https://zakon.rada.gov.ua/laws/main/929_025 (дата звернення: 22.11.2019).

4. НП(С)БО 1 «Загальні вимоги до фінансової звітності: Положення від 07.02.2013 № 73. URL: https://zakon.rada.gov.ua/laws/main/z0336-13 (дата звернення: 22.11.2019).

5. Панченко I.А. Внутрішня звітність про фінансові результати діяльності у форматі запитів користувачів. Проблеми теорії та методології бухгалтерського обліку, контролю і аналізу. Вип. 2 (23). 2012. С. 253-261.

6. Податковий кодекс України: Кодекс України від 02.12.2010 № 2755-VI URL: https://zakon.rada.gov.ua/laws/main/2755-17 (дата звернення: 22.11.2019).

7. П(С)БО 15 «Дохід»: Положення від 29.11.1999 № 290 URL: https://zakon.rada.gov.ua/laws/main/z0860-99 (дата звернення: 22.11.2019).

8. Про бухгалтерський облік та фінансову звітність в Україні: Закон України від 16.07.1999 р. № 996-XIV. URL: https://zakon.rada.gov.ua/laws/show/996-14 (дата звернення: 22.11.2019).

9. Прохар Н.В., Ночовна Ю.О. Облік доходів, витрат і фінансових результатів: проблеми теорії та практики: монографія]. Полтава: РВВ ПУЕТ. 2011. 257 с.

10. Слободняк И.А. Система форматов внутренней бухгалтерской управленческой отчетности. Известия ИГЭА. № 4 (72). 2010. С. 32-37.

*УДК 351.84

Шубалий О.М., д.е.н., професор

Андрусик I.O.

Луцький національний технічний університет

\section{НАПРЯМИ ВДОСКОНАЛЕННЯ СИСТЕМИ НАДАННЯ СОЦІАЛЬНИХ ДОПОМОГ НАСЕЛЕННЮ В УКРАЇНІ}

У статті проведено оцінку стану і обгрунтовано перспективні напрями вдосконалення системи надання допомог населенню на прикладі України.

Ключові слова: соціальний захист, доходи населення, соціальні допомоги, соціальне забезпечення, допомога, населення, країна.

* Шубалий О.М., Андрусик I.О. 